\title{
К ВОПРОСУ О СТАНОВЛЕНИИ АСТРОПОЛИТИКИ
}

\begin{abstract}
Аннотация: В статье рассматривается процесс становления «астрополитики», его соотношение с «космической политикой», «геополитикой» и «астростратегией». Отражены основные дискуссионные моменты того, что же на самом деле отражает термин «астрополитика». Анализируются труды американского политолога, профессора Школы перспективных аэрокосмических исследований ВВС США Э. Долмана в области астрополитики, геополитике и освоения космического пространства. Так же рассматриваются и анализируются основные взгляды известного политолога Л. Савина на труды Э. Долмана. Акиентируется внимание на том, что все научные труды Э. Долмана будут еще долгое время вызывать не мало споров и разногласий. В статье подробно описываются основные положения, которые американский политолог исследовал и доказывал в своих трудах. Делаются выводы о значимости исследований этого ученого.
\end{abstract}

Review: The article regards the process of formation of the "astro-policy", its correlation with the "space policy", "geopolicy" and "astro-strategy". The author analyzes the topical issues regarding the true nature of the term "astro-policy", as well as the works of the American political scientist, Professor of the USAF Air University: School of Advanced Air and Space Studies E. Dolman. in the sphere of astro-policy, geo-policy and cosmic exploration. The author also evaluates and analyzes the views of the renowned political scientist L. Savin and his attitude to the work of E. Dolman. The attention is brought to the fact that the scientific works of E. Dolman shall be topical for a long time, causing disputes and disagreements. The article provides detailed analysis of the key provisions of the works of the American political scientist and the conclusions are made on the value of his research.

Ключевые слова: Политология, астрополитика, астростратегия, астрополитический тренд, астрополитические теории, эволюиия, космическая политика, геополитика, космическое пространство, трансформация Keywords: political science, astro-policy, astro-strategy, astro-political trend, astro-political theory, evolution, space policy, geo-policy, space, transformation.

(1) ермин «астрополитика» (Astropolitik, или Astropolitics) появился сравнительно недавно, благодаря нашему современнику - американскому политологу Эверету Долману (Everett C. Dolman), профессору Школы перспективных аэрокосмических исследований ВВС США, на авиабазе Максвелл в Алабаме. Профессор активно занимается космическими исследованиями с 1982 г. и сотрудничал с правительством США как политический аналитик-международник.

Гонка вооружений, процесс, подломивший экономику СССР, была именно астрополитическим процессом. «Звездные войны», «Империя Зла» - «фирменные «брэнды» администрации Рональда Рейгана - это уже астрополитические индикаторы в истории взаимоотношений цивилизаций. Если во главу угла ставится захват двухмерного пространства, то развиваются технологии перемещения и соответствующие виды вооружения. Однако все подобные манипуляции теряют смысл, если приоритеты начинают расставляться в соответствии с АП-задачами. Менее востребованы становятся громоздкие сухопутные силы, Морская Сила не находит достойного применения. Доктринальный переход к использованию сил оперативного реагирования - это также явный астрополитический тренд. ${ }^{1}$

В своей статье «Геостратегия в космическую эпоху: астрополитический анализ», опубликованной в США в 2003 г., он определяет этот термин следующим образом: «В этом коротком эссе я пытаюсь охватить сущность классической геополитики, распространив

\footnotetext{
${ }^{1}$ Подробней см.: Жданов В. Астрополитика и национальная космическая доктрина США/ В. Жданов // Обозреватель. 2010. № 4. С. 91.
} 
DOI: $10.7256 / 1811-9018.2013 .9 .7695$

При цитировании этой статьи сноска на dоі обязательна

Правовая и политическая мысль

её в царство внешнего пространства. Именно это я и назвал 'астрополитика'»².

Другая дефиниция термина дана Долманом годом раньше в его нашумевшей книге «Астрополитика: классическая геополитика в космическую эру»: здесь он определяет ее как «исследования взаимосвязей между космическим пространством, технологией и развитием политической и военной стратегии» ${ }^{3}$.

Термин «астрополитика» несколько уже, чем «космическая политика», однако он представляется более удобным для использования, где речь идет о геополитических категориях. Исследователи употребляют и еще один термин - «астростратегия»: если астрополитику понимать как «продолжение» геополитики космическими средствами, то, соответственно, астростратегия понимается как «распространение» в космос геополитических стратегий.

По мнению Э. Долмана, мы имеем дело с «продолжающимся процессом уточнения геополитических теорий», причем разработка и внедрение космических технологий - и, шире, реализация тех или иных космических проектов - представляются ему очередными ступенями этого процесса, его новейшими фазами.

В работе «Астрополитика» Долман рассматривает, как физические характеристики космического пространства и характеристики космических систем «оформляют» и детерминируют практическое применение государствами своей космической мощи, а затем использует этот «астрополитический» анализ, предлагая разработать меры для поддержки «рыночной экономики в космосе»: по мнению Долмана, такой «неоклассический рыночно-ориентированный подход» призван обеспечить человечеству «максимальную эффективность и процветание» и способствовать глобальной безопасности ради общего блага

Э. Долман начинает свое исследование, отсылая читателя к немецким истокам геополитики; отдавая должное реальному вкладу германских ученых в эту область науки, он в то же время виртуозно развенчивает теоретические построения, прямо послужившие становлению нацистской идеологии. Далее геополитический анализ в исполнении Долмана плавно перетекает в анализ астрополитический: в полном

\footnotetext{
${ }^{2}$ Dolman, E. C. Geostrategy in the Space Age. // Geopolitics, Geography and Strategy. / Ed. C. S. Gray and G. Sloan. Portland, Oregon: Frank Cass, 2003. P. 83

${ }^{3}$ Dolman , E.C. Astropolitik: classical geopolitics in the space Age. London: Frank Cass Publishers, 2002. P. 15.
}

соответствии с одним из определений, данных им термину «астрополитика», автор «распространяет» рассмотренные им геополитические принципы за пределы собственно Земли. Следуя подходам, разработанным в геополитике, Долман разделяет на, так сказать, «панрегионы» уже даже не Землю - а Солнечную систему. Таких регионов он выделяет 4:

1) Terra (Земля и ближний космос);

2) так называемые терран-пространства - орбиты непосредственно над геостационарной;

3) «лунный» космос (от терран-пространств до лунной орбиты);

4) «солнечный» космос ${ }^{4}$ (вся остальная Солнечная система; здесь нужно уточнить, что словами «пространство» и «космос» мы переводим слово space, которое употребляет в соответствующих случаях Долман).

Серьезное внимание автор уделяет астрополитическому значению геостационарной орбиты, «точек Лагранжа» (иначе «точек либрации»- вот одно из возможных их описаний: это зоны космического пространства, «где движение тел стабилизировано суммарным тяготением Солнца и Земли» ${ }^{5}$ ), радиационных поясов Ван Алена, а также преимуществам и недостаткам конкретных объектов космического запуска. Несложно заметить, какое значение придает он данному - первому в составленном им реестре «региону»; вот дословное изречение Долмана: «Кто контролирует низкую околоземную орбиту - контролирует ближний космос. Кто контролирует ближний космос - доминирует в Терре (мы используем здесь предлог «в», поскольку речь идет о «регионе» - В.Ж.). Кто доминирует в Терре, определяет судьбу всего человечества...» ${ }^{6}$

Э. Долман утверждает, что конечная цель как Astropolitik (астрополитических теорий), так и astropolitics (их практического применения) - не милитаризация космического пространства; скорее, такая милитаризация видится ему одним из средств достижения цели, частью долгосрочной «астростратегии». Цель же состоит в том, чтобы «исцелить» наметившуюся в исследованиях космоса стагнацию - причем сделать это таким способом, который учитывал бы позитивные мотивы и интересы всех

\footnotetext{
${ }^{4}$ Там же. Р. 69-70.

${ }^{5}$ Штерн Б. Планк и Гершель в точке Лагранжа // Троицкий вариант. Наука. 21. 06. 09 (№33). С. 12.

${ }^{6}$ Dolman , E.С. Указ. соч.
} 
DOI: 10.7256/1811-9018.2013.9.7695

При цитировании этой статьи сноска на dоі обязательна

\section{Право и политика 9 (165) $\bullet 2013$}

государств (и даже частных лиц), стремящихся улучшить свое положение... Цель декларируется благая - однако предлагаемые автором астрополитические средства ее достижения сами по себе «астрополитичны» (как и любое политическое учение выступает феноменом в первую очередь политическим...): по убеждению профессора Долмана, миссией именно США, как единственной на нынешний период сверхдержавы и выдающийся космической державы, является утверждение в космическом пространстве «гегемонии» свободного рынка ${ }^{7} \ldots$ хотя в работе и подчеркивается, что Америке необходимо стремиться соблюдать баланс интересов в космосе.

Работа Э. Долмана вызвала широкий резонанс. В частности, такой авторитетный журнал, как «Air and Space Power» (чьи рецензенты обычно проявляют похвальную уравновешенность и академическую объективность), отозвался на ее появление в самых восторженных тонах. Книга, говорится в рецензии, «является ошеломляющим интеллектуальным достижением», «продолжает лучшие интеллектуальные традиции геополитики и вносит существенный вклад в диалог ученых о взаимосвязи между космическим пространством и национальной безопасностью»; «возможно, это наиболее важная книга в области космической деятельности и безопасности, вышедшая с момента опубликования в 1985 г. работы Мак-Дугалла «Небеса и земля: политическая история космической эры», завоевавшей Пулитцеровскую премию...» ${ }^{8}$

Авторы отзыва в «Air and Space Power» признают все же, что, «бросая вызов традиционному мышлению», «Астрополитика» Эверета Долмана спровоцирует еще немало споров и разногласий. «Однако одним из признаков великой книги является то, что она помогает определить структуру последующих дискуссий..., предоставив терминологию и линии аргументации для будущих дискуссий...». Что ж, насчет будущих дискуссий они не ошиблись. Хотя за несколько лет, прошедших со дня выхода книги в свет, Долман обрел статус отца-основателя и мэтра «астрополитики», - восприятие некоторых ее положений никак не назовешь однозначным. Приведем в пример выступление Леонида Савина, и само по себе

\footnotetext{
${ }^{7}$ Dolman , E.C. Указ. соч. Р. 157.

${ }^{8}$ Review Essay // Air and Space Power. 2002. Vol. XVI, №3. P. 104-107.

9 Там же. Р. 106.
}

прозвучавшее достаточно «громко» (Л. Савин - автор и ведущий нескольких политических программ на Евразия-TV; одна из его авторских программ, «Астрополитика: меч обоюдоострый», была также широко растиражирована в Интернете, и не только в русскоязычном).

«Геополитика как школа мысли оперирует в основном с представлениями о господстве посредством моря и посредством суши. После запуска первого искусственного спутника Земли заговорили о господстве посредством космоса...» ${ }^{10}$

Процитировав ключевое, на его взгляд, положение Э. Долмана «Покорение космоса должно стать моральным императивом, необходимым для выживания человеческой расы и ее доминирования в этой сфере», Л. Савин трактует его следующим образом: «Имеется в виду не абстрактная «человеческая раса», а ее англосаксонский подвид, сформировавшийся в борьбе с себе подобными на широких просторах Земли. Здесь «дух фронтира», воспетый Фредериком Джексоном Тернером еще в конце XIX в. и рвущийся уже к звездным высотам. Если во времена Тернера «дух фронтира» звал к истреблению под корень многочисленных индейских племен, то сейчас США не прочь повторить этот эксперимент на космическом уровне. Не случайно в Америке появился сериал «Звездные войны», а вместе с ним и другие ставшие культовыми и кассовыми фантастические боевики. Например, фильм «Аватар» - это очередной рецидив коллективного бессознательного носителя «духа фронтира», мутировавшего в техногенную форму и вооружённого методами культурноинформационной манипуляции...»" ${ }^{11}$

31 августа 2006 г. президент США подписывает новую «Национальную космическую политику США», чьи ключевые «настроения» словно навеяны обсуждавшейся уже нами работой Долмана «Астрополитика». В этом программном документе говорится, что «свобода действий в космосе столь же важна для США, как и обладание воздушной и морской силами» ${ }^{12}$.

\footnotetext{
${ }^{10}$ Савин Л. Астрополитика: меч обоюдоострый. // Фонд стратегической культуры. Электронное издание. 22. 02. 2010. URL: http:// www.fondsk.ru/article.php?id=2801

${ }^{11}$ Там же.

${ }^{12}$ Национальная космическая доктрина США.// URL: http://astropolitics.com .Адрес электронного документа дан по состоянию на 13 сентября 2007 г.
} 
DOI: $10.7256 / 1811-9018.2013 .9 .7695$

При цитировании этой статьи сноска на доі обязательна

Правовая и политическая мысль

Налицо трансформация геополитических категорий в астрополитические: от «Sea Power» Мэхэна к современному понятию «космический потенциал» страны (Space Capabilities). «США считают космический потенциал, включая как наземные, так и космические сегменты и существующие между ними связи, жизненно важным для своих национальных интересов. В соответствии с этой политикой Соединенные Штаты будут защищать свои права, инфраструктуру и свободу действий в космосе; силой убеждения удерживать остальных от создания препятствий или развития инфраструктурных объектов, способных наложить ограничения на реализацию этих прав; принимать те меры, которые необходимы для защиты своего космического потенциала; реагировать на помехи и, если потребуется, отвергать право противника на использование космического потенциала враждебно по отношению к национальным интересам США» ${ }^{13}$.

Сложно не согласиться с озвученной Л. Савиным мыслью, наблюдая попытки, предпринимаемые США с целью сохранить и утвердить свое доминирование на планете и в космосе. Однако вклад Эверета Долмана в «космическую» эволюцию геополитических учений, в частности в процесс становления «астрополитики», при всей дискуссионности некоторых его подходов, следует признать несомненным и очень значительным.

\section{Библиография:}

1. Dolman, E. C. Geostrategy in the Space Age. // Geopolitics, Geography and Strategy. / Ed. C. S. Gray and G. Sloan. Portland, Oregon: Frank Cass, 2003. P. 83.
2. Dolman, E.C. Astropolitik: classical geopolitics in the space Age. London: Frank Cass Publishers, 2002. P. 15.

3. Жданов В. Астрополитика и национальная космическая доктрина США/ В. Жданов // Обозреватель. 2010. № 4. C. 91.

4. Национальная космическая доктрина США.// URL: http://astropolitics.com .Адрес электронного документа дан по состоянию на 13 сентября 2007 г.

5. Review Essay // Air and Space Power. 2002. Vol. XVI, №3. P. 104-107.

6. Савин Л. Астрополитика: меч обоюдоострый. // Фонд стратегической культуры. Электронное издание. 22. 02. 2010. URL: http://www.fondsk.ru/ article.php?id $=2801$

7. Штерн Б. Планк и Гершель в точке Лагранжа // Троицкий вариант. Наука. 21. 06. 09 (№ 33). С. 12.

\section{References (transliteration):}

1. Dolman, E. C. Geostrategy in the Space Age. // Geopolitics, Geography and Strategy. / Ed. C. S. Gray and G. Sloan. Portland, Oregon: Frank Cass, 2003. P. 83.

2. Dolman, E.C. Astropolitik: classical geopolitics in the space Age. London: Frank Cass Publishers, 2002. R. 15.

3. Zhdanov V. Astropolitika i nacional'naya kosmicheskaya doktrina SShA/ V. Zhdanov // Obozrevatel'. 2010. № 4. C. 91.

4. Savin L. Astropolitika: mech oboyudoostryy. // Fond strategicheskoy kul'tury. Elektronnoe izdanie. 22. 02. 2010. URL: http://www.fondsk.ru/article.php?id=2801

5. Shtern B. Plank i Gershel' v tochke Lagranzha // Troickiy variant. Nauka. 21. 06. 09 (№ 33). S. 12.

\footnotetext{
${ }^{13}$ Там же.
} 